\title{
IMPLEMENTASI KONTROL ARUS PADA INVERTER SATU FASA MENGGUNAKAN DSPIC30F4011 DENGAN METODE KONTROL HYSTERESIS
}

\author{
Ferry Aditya Sandjojo*), Iwan Setiawan dan Trias Andromeda \\ Departemen Teknik Elektro, Universitas Diponegoro \\ Jl. Prof. Sudharto, SH, Kampus UNDIP Tembalang, Semarang 50275, Indonesia \\ ${ }^{*}$ E-mail : ferryaditya863@gmail.com
}

\begin{abstract}
Abstrak
Inverter merupakan perangkat yang umum digunakan sebagai konverter untuk mengubah tegangan DC ke AC. Aplikasi inverter yang sering dijumpai adalah pada sistem photovolaic yang tersambung dengan grid dimana kualitas arus keluaran inverter sangat berpengaruh terhadap kualitas daya, serta pada UPS dengan daya rendah hingga menengah dimana arus keluaran inverter harus dikontrol untuk meningkatkan performa UPS. Dibandingkan dengan inverter PWM open loop, inverter dengan kontrol arus memiliki beberapa keunggulan diantaranya respon sistem yang lebih cepat dan memiliki akurasi tinggi dalam pengontrolan. Salah satu metode yang umum digunakan untuk mengontrol arus keluaran inverter adalah kontroler arus histeresis, dimana arus keluaran inverter dan referensi yang diberikan dibandingkan dalam batas histeresis tertentu. Metode kontrol ini banyak digunakan karena sederhana, respon sistem yang cepat dan robust terhadap perubahan beban. Dalam penelitian ini, dirancang inverter satu fasa Full Bridge dengan metode kontrol arus histeresis menggunakan mikrokontroler 16-bit DSPIC30F4011. Arus keluaran inverter diumpan-balikkan oleh sensor arus ACS712-05B. Pengujian dilakukan dengan rentang referensi arus sebesar $1-3$ A pada variasi beban $4,6 \Omega$ dan $9,4 \Omega$. Hasil pengujian menunjukkan gelombang arus keluaran inverter mampu mengikuti referensi arus yang diberikan. Ratarata error pada arus keluaran inverter adalah $0,55 \mathrm{~A}$ untuk beban $4,6 \Omega$ dan $0,06 \mathrm{~A}$ untuk beban $9,4 \Omega$.
\end{abstract}

Kata Kunci : Kontrol Arus, Histeresis, Inverter, DSPIC30F4011.

\begin{abstract}
Inverter is the most commonly used device to convert DC to AC voltage. Application of inverter is often found in grid connected photovoltaic systems where power quality depends on output current quality and also in low and medium power UPSs where inverter output current needs to be controlled to improve UPS's performance. Compared to the openloop PWM inverters, the current-controlled inverters have some advantages such as quick system response and high accuracy. One of the most common current control methods to control the inverter output current is hysteresis current control, where inverter output current is compared with reference current in a specific hysteresis band. This current control method is often used because of its quick system response and robustness towards load parameter change. In this research, a Full Bridge inverter with hysteresis current control is designed using 16-bit microcontroller DSPIC30F4011. Inverter output current is fed-back by current sensor ACS712-05B. Experiment is done with reference current range of $1-3 \mathrm{~A}$ at $4,6 \Omega$ and $9,4 \Omega$ loads. Experiment result shows that inverter output current waveform is able to follow the given reference current. Inverter output current average error is $0,55 \mathrm{~A}$ for $4,6 \Omega$ load and $0,06 \mathrm{~A}$ for $9,4 \Omega$ load.
\end{abstract}

Keywords : Current Control, Hysteresis, Inverter, DSPIC30F4011.

\section{Pendahuluan}

Inverter merupakan perangkat yang paling umum digunakan sebagai konverter untuk mengubah tegangan DC ke dalam tegangan AC. Salah satu aplikasi inverter yang paling sering dijumpai adalah pada sistem photovoltaic yang tersambung dengan grid, dimana tegangan yang terhubung pada sistem grid tidak dapat dikontrol [1]. Kualitas arus keluaran inverter sangat berpengaruh terhadap kualitas daya. Contoh aplikasi lain inverter adalah pada Uninterruptable Power Supply (UPS) dengan daya rendah hingga menengah [2]. Untuk meningkatkan performa UPS, inner current controller biasa digunakan untuk mengontrol arus keluaran inverter. Salah satu metode untuk mengontrol arus keluaran inverter adalah kontroler arus histeresis. Kontroler arus histeresis membandingkan arus keluaran inverter dengan referensi yang diberikan dalam batas histeresis tertentu. Metode ini 
cukup banyak digunakan karena pengimplementasian yang sederhana, biaya pembuatan yang relatif murah, respon sistem yang cepat, dan tidak mudah terpengaruh oleh variasi parameter beban [2].

Penelitian tentang inverter yang terhubung dengan grid menggunakan kontroler arus histeresis yang dilakukan dalam penelitian [3] menggunakan mikrokontroler ATMega 16 sebagai pembaca nilai arus yang diinformasikan oleh sensor arus pembangkit sinyal kontrol, namun masih menggunakan rangkaian logika terpisah sebagai kontroler histeresisnya. Penelitian pada [4] membahas skema kontroler histeresis band adaptif untuk inverter yang terhubung dengan grid. Pada penelitian [5] dibahas mengenai metode kontroler arus histeresis pada konverter AC ke DC menggunakan PWM.

Penelitian ini merancang kontroler arus histeresis yang akan diimplementasikan pada inverter satu fasa tipe Full Bridge. Kontroler arus histeresis untuk inverter satu fasa yang akan dirancang terlebih dahulu disimulasikan menggunakan perangkat lunak MATLAB R2013a untuk memastikan apakah sistem memungkinkan untuk dirancang. Sinyal kontrol histeresis dibangkitkan oleh mikrokontroler 16-bit DSPIC30F4011. Frekuensi kerja inverter diatur konstan sebesar $50 \mathrm{~Hz}$. Arus referensi inverter dapat divariasikan dalam rentang $0-3$ ampere peak $\left(I_{m}\right)$. Diharapkan tegangan dan arus keluaran inverter dapat memiliki respon yang cepat terhadap referensi yang diberikan dan perubahan beban, serta memiliki gelombang yang mendekati sinusoidal.

\section{Metode}

Gambar 1. merupakan blok diagram perancangan perangkat keras inverter satu fasa dengan kontroler arus histeresis. Perancangan ini terdiri beberapa blok utama yaitu blok suplai AC 1 fasa, rangkaian daya, rangkaian control, sensor arus ACS712-05B, Digital to Analog Converter AD7302, dan blok beban. Pada rangkaian kontrol terdapat rangkaian mikrokontroler DSPIC30F4011 dan rangkaian driver MOSFET TLP250. Pada rangkaian daya terdapat full wave bridge rectifier sebagai sumber daya DC masukan inverter dan inverter satu fasa tipe Full Bridge.

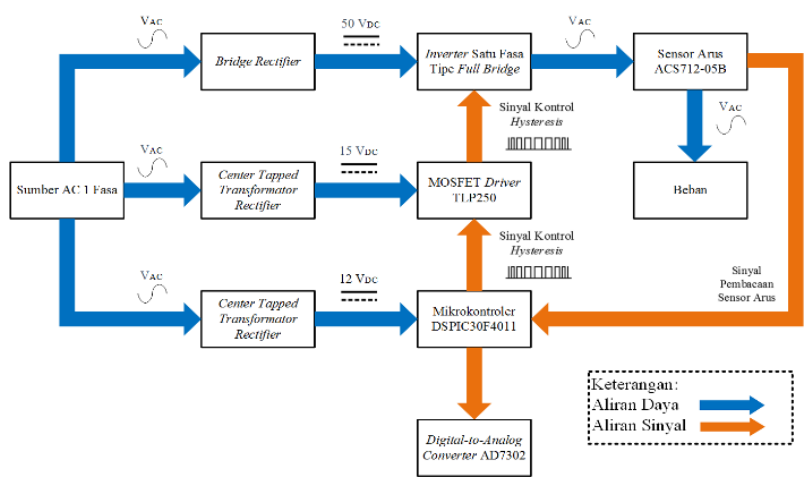

Gambar 1. Blok Diagram Perangkat Keras

\subsection{MOSFET Driver TLP250}

Rangkaian TLP250 digunakan untuk mengisolasi dan menguatkan sinyal kontrol histeresis dengan level tegangan 5 Volt yang dibangkitkan oleh mikrokontroller DSPIC30F4011 menjadi level tegangan yang lebih tinggi dengan sistem ground terpisah (level tegangan 15 Volt) dan cukup untuk memicu MOSFET (Metal Oxide Semiconductor Field Effect Transistor) sebagai driver [6], [7].

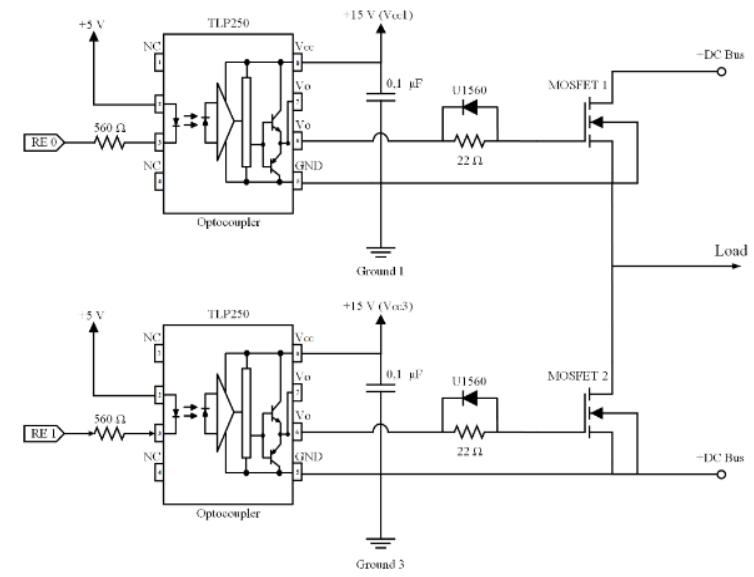

\section{Gambar 2. Rangkaian MOSFET Driver TLP250}

MOSFET sisi atas (high-side) terhubung dengan optocoupler yang memiliki suplai DC terpisah dengan fasa lain dan MOSFET Driver sisi low, sedangkan MOSFET pada sisi bawah (low-side) terhubung dengan rangkaian optocoupler yang memiliki titik referensi ground yang sama dengan MOSFET Driver sisi low pada fasa yang lain [8].

\subsection{Sensor Arus ACS712-05B}

Sensor arus ACS712-05B digunakan sebagai perangkat pengukuran dan pembacaan nilai arus aktual yang melalui beban dalam perancangan penelitian ini. Sensor ini bekerja dengan prinsip hall effect. Arus yang mengalir melewati sensor akan dibaca dan dikonversikan menjadi nilai tegangan yang proporsional, kemudian sinyal berupa tegangan tersebut akan dibaca oleh modul ADC pada mikrokontroler DSPIC30F4011.

Tegangan keluaran sensor akan bernilai sekitar 2,5 V saat tidak ada arus yang mengalir melewati sensor. Berdasarkan datasheet, sensitivitas sensor arus ACS712-05B ini adalah sebesar $185 \mathrm{mV} / \mathrm{A}$ [9], namun jenis sensor yang digunakan sudah dilengkapi IC op-amp atau penguat sinyal TLC2272ACD yang dapat digunakan untuk mengatur nilai offset dan gain melalui dua potensiometer yang dihubungkan pada IC op-amp tersebut. Potensiometer gain diatur hingga nilai sensitivitas sensor berubah menjadi 0,5 V/A, sehingga nilai tegangan keluaran maksimal dari 
sensor saat arus yang terbaca sebesar 5 A sesuai dengan Persamaan 1 berikut.

$$
\begin{aligned}
& V_{\text {out }}=2,5+0,5 \cdot i \\
& V_{\text {out }}=2,5+0,5 \cdot 5 \\
& V_{\text {out }}=5 \mathrm{~V}
\end{aligned}
$$

Tegangan keluaran sensor diatur menjadi maksimal $5 \mathrm{~V}$ untuk memudahkan pembacaan oleh modul analog-todigital converter yang memiliki tegangan referensi sebesar $5 \mathrm{~V}$.

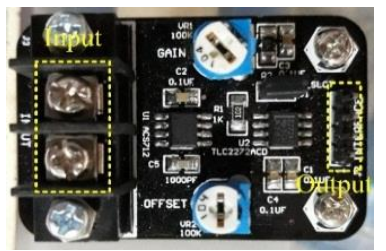

Gambar 3. Sensor Arus ACS712-05B

\subsection{Inverter Satu Fasa dengan Kontrol Arus Histeresis}

Sinyal kontrol histeresis yang digunakan untuk memicu gate MOSFET pada inverter diperoleh dengan cara membandingkan nilai kesalahan atau error $e(k)$ dan batas histeresis yang telah ditentukan. Nilai error diperoleh dari hasil pengurangan nilai arus aktual yang diukur oleh sensor arus $\left(i_{a c t}\right)$ dan nilai referensi arus yang diberikan lewat potensiometer $\left(i_{r e f}\right)$ [3]. Setelah nilai $e(k)$ didapatkan, kontroler akan membandingkannya dengan batas histeresis atas dan batas histeresis bawah untuk menghasilkan sinyal kontrol .
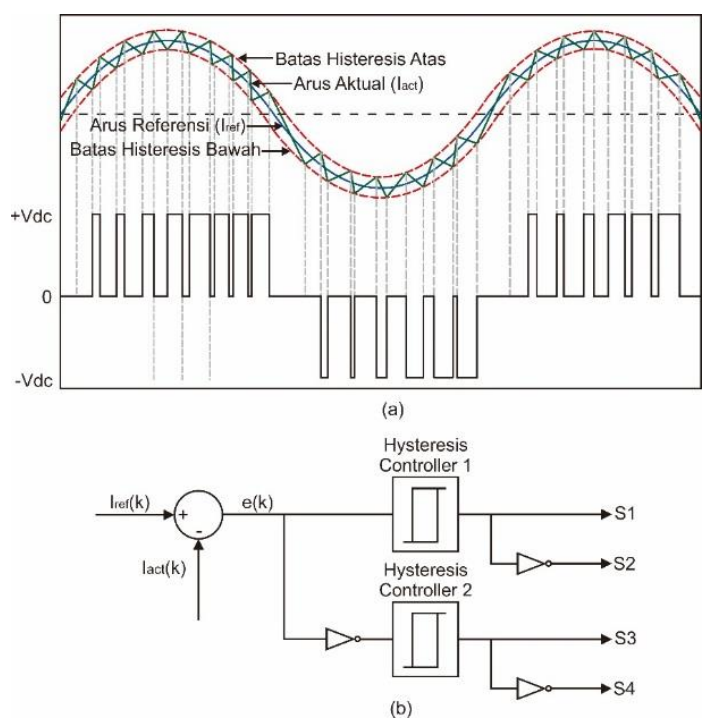

Gambar 4. (a) Arus dan Tegangan Keluaran Inverter, (b) Blok Kontroler Histeresis

Untuk membangkitkan sinyal kontrol histeresis dalam satu leg pada inverter, maka kontroler perlu membandingkan nilai error dan batas histeresis dengan ketentuan sebagai berikut [10].

* Jika $e(k)>U P P H Y S$ maka sinyal kontrol $=1$.

* Jika $e(k)<L O W H Y S$ maka sinyal kontrol = 0 .

Dimana UPPHYS adalah batas histeresis atas dan LOWHYS adalah batas histeresis bawah.

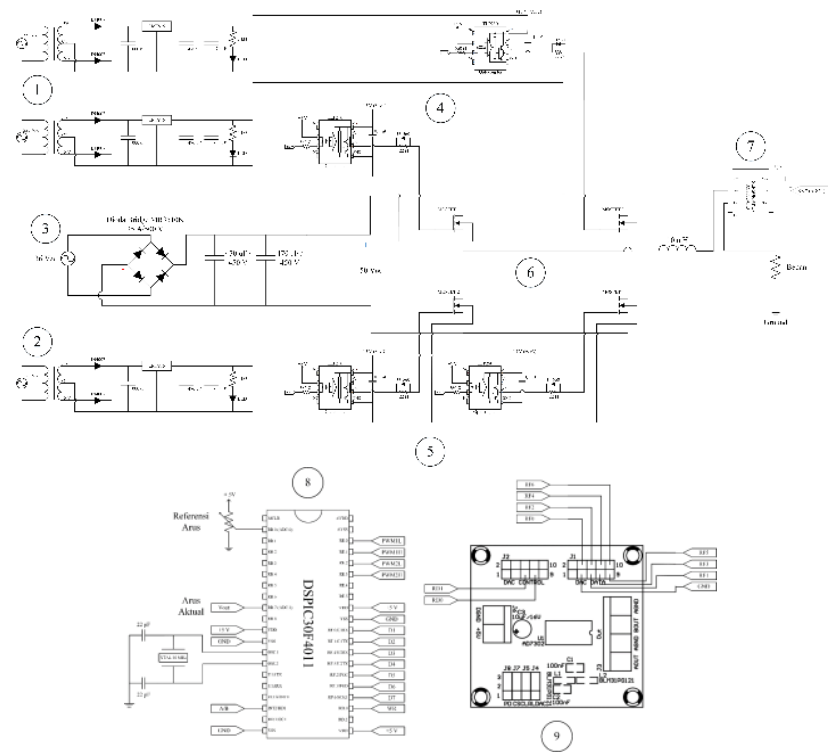

Gambar 5. Rangkaian Inverter Satu Fasa dengan Kontroler Arus Histeresis

\subsection{Kontroler Arus Histeresis}

Untuk mengendalikan nilai arus aktual keluaran inverter agar dapat mengikuti referensi, mikrokontroler DSPIC30F4011 harus membangkitkan sinyal kontrol dengan band histeresis. Sinyal kontrol histeresis dibentuk dengan menghitung selisih antara arus aktual keluaran inverter yang dibaca oleh sensor dengan arus referensi yang berupa sinyal sinus, kemudian nilai error yang didapatkan dibandingkan dengan batas histeresis yang telah ditentukan [11].

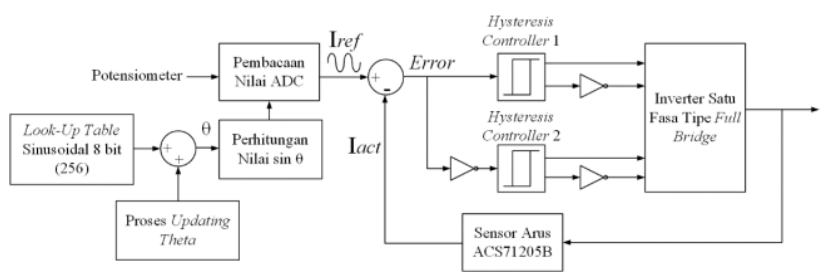

Gambar 6. Diagram Blok Kontroler Arus Histeresis

Pembentukan sinyal kontrol histeresis pada Gambar 6 berdasarkan pada nilai error $(e(k))$ yang merupakan selisih antara arus akual dan arus referensi, yang kemudian dibandingkan dengan batas histeresis atas dan bawah yang nilainya dapat diatur. Saat sistem dinyalakan maka kontroler akan berada dalam keadaan STANDBY. Jika nilai $e(k)$ lebih besar dari batas histeresis atas maka kontroler 
akan mengalami transisi ke dalam keadaan $H I G H$ dimana sinyal kontrol $=1$, sementara jika nilai $e(k)$ lebih kecil dari batas histeresis bawah maka kontroler akan bertransisi ke dalam keadaan $L O W$ dimana sinyal kontrol $=0$. Siklus tersebut akan terus mengalami perulangan selama sistem menyala sehingga membentuk sinyal kontrol histeresis.

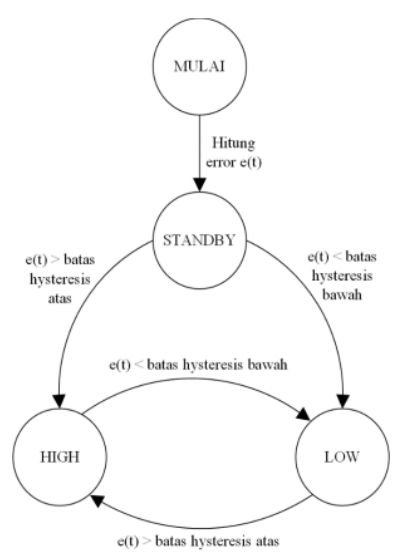

Gambar 7. Skema Pembentukan Sinyal Kontrol Histeresis

\section{Hasil dan Analisa}

\subsection{Pengujian Gelombang Keluaran Rangkaian Kontrol}

\subsubsection{Pengujian Gelombang Keluaran DSPIC30F4011}

Pengujian dilakukan untuk memastikkan bahwa modul PWM pada DSPIC30F4011 dapat membangkitkan sinyal kontrol dalam mode komplementer dengan adanya dead time sebesar $2 \mathrm{uS}$ antara pin PWMxL dan PWMxL. Pengujian dilakukan dengan program PWM open loop dengan frekuensi PWM $20 \mathrm{kHz}$

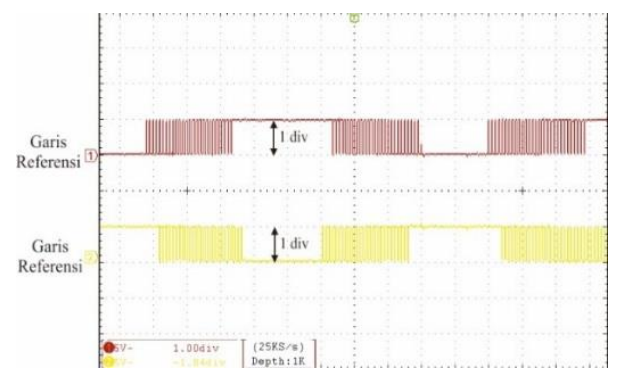

Gambar 9. Gelombang Keluaran PWM Open Loop

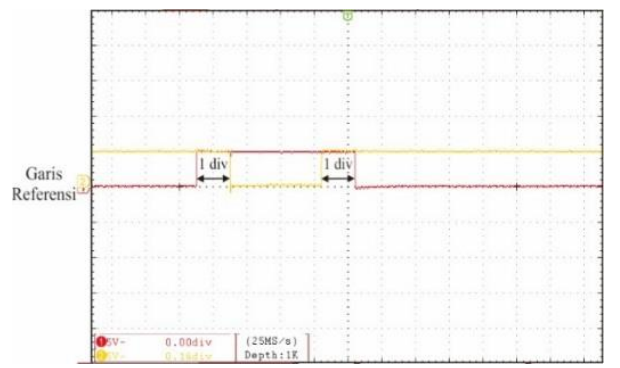

Gambar 10. Dead Time pada Keluaran PWM Open Loop
Hasil pengujian keluaran DSPIC30F4011 pada SPWM open loop menunjukkan bahwa sinyal kontrol bekerja dalam mode komplementer serta adanya dead time sebesar $2 \mathrm{uS}$ antara PWM sisi high dan PWM sisi low.

\subsubsection{Pengujian Gelombang Keluaran MOSFET Driver TLP250}

Pengujian pada rangkaian ini dilakukan untuk mengetahui dan memastikan gelombang tegangan keluaran dari MOSFET driver TLP250 telah sesuai dengan perancangan dan dapat digunakan untuk pemicuan MOSFET.

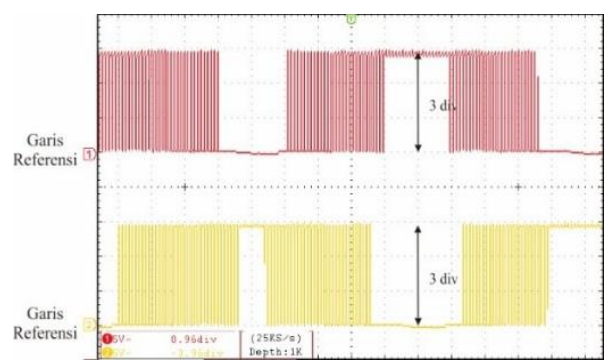

Gambar 11. Gelombang Keluaran Driver MOSFET TLP250

Hasil pengujian gelombang keluaran dari MOSFET driver TLP250 telah sesuai dengan perancangan dan dapat digunakan untuk memicu MOSFET.

\subsection{Pengujian Sensor Arus ACS712-05B}

Pengujian sensor arus ACS712-05B dilakukan dengan mengukur tegangan keluaran sensor yang telah dikalibrasi sebelumnya saat dialiri arus sebesar 5 A. Arus diberikan dengan cara memasang beban resistif secara seri dengan sumber tegangan $\mathrm{AC}$ yang diatur sedemikian rupa hingga nilai arus yang mengalir adalah $5 \mathrm{~A}$.

Nilai arus yang diukur oleh sensor direpresentasikan secara proporsional oleh tegangan keluaran sensor. Sebelumnya pada perancangan sensor arus telah diatur nilai offset tegangan keluaran sensor adalah $2,5 \mathrm{~V}$ dan sensitivitas pembacaan arus oleh sensor adalah 0,5 V/A.

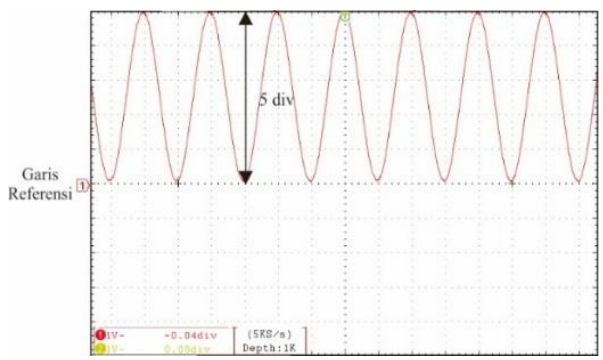

Gambar 12. Gelombang Keluaran Sensor Arus ACS712-05B $(\mathbf{I}=5 \mathrm{~A})$

Nilai tegangan puncak ke puncak pada pengujian sensor dalam Gambar 12 memiliki jumlah div 5 dengan skala 
$\mathrm{V} / \mathrm{div}=1 \mathrm{~V}$ dengan faktor pengali probe $1 \mathrm{x}$. Hal ini sudah sesuai dengan perancangan dimana saat arus $=5 \mathrm{~A}$ maka diperoleh tegangan keluaran sensor sebagai berikut.

$$
\begin{aligned}
& V_{\text {out }}=2,5+0,5 \cdot i \\
& V_{\text {out }}=2,5+0,5 \cdot 5 \\
& V_{\text {out }}=5 \mathrm{~V}
\end{aligned}
$$

\subsection{Pengujian Keluaran Inverter Satu Fasa dengan SPWM Open Loop}

\subsubsection{Pengujian Tegangan Keluaran Inverter}

Pengujian ini dilakukan untuk mengetahui bentuk Pengujian bertujuan untuk mengamati bentuk gelombang dan magnitude tegangan keluaran inverter satu fasa yang dipicu oleh SPWM open loop. Referensi arus yang diberikan adalah sebesar $2 \mathrm{~A}$. Arus keluaran inverter tidak diumpan-balikkan pada sistem. Hasil pengujian tegangan keluaran inverter dengan SPWM open loop pada beban 4,6 $\Omega$ dan $9,4 \Omega$.

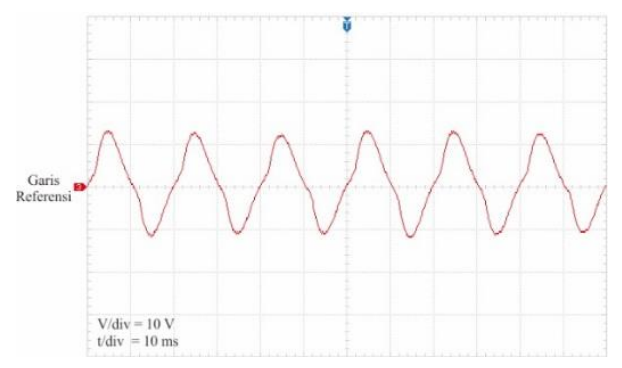

Gambar 13. Tegangan Keluaran Inverter Open Loop dengan Beban 4,6 $\Omega$ pada Referensi 2 A.

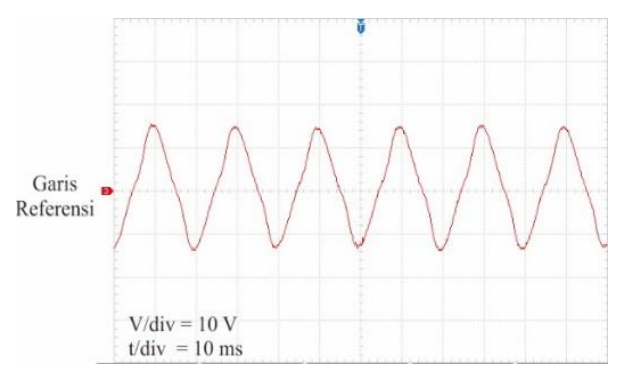

Gambar 14. Tegangan Keluaran Inverter Open Loop dengan Beban 9,4 $\Omega$ pada Referensi 2 A.

Hasil pengujian tegangan keluaran inverter open loop pada referensi arus 2 A menunjukkan bahwa nilai tegangan keluaran akan berubah saat inverter mengalami perubahan beban. Nilai tegangan rms yang terukur pada multimeter adalah $8,43 \mathrm{~V}$ untuk beban $4,6 \Omega$ dan $9,9 \mathrm{~V}$ untuk beban $9,4 \Omega$. Hal ini cukup mendekati teori dimana nilai tegangan berbanding lurus dengan nilai resistansi pada beban.

\subsubsection{Pengujian Arus Keluaran Inverter}

Pengujian bertujuan untuk mengamati bentuk gelombang dan magnitude arus keluaran inverter satu fasa yang dipicu oleh SPWM open loop. Arus keluaran diamati melalui tegangan keluaran DAC. Tegangan DAC tersebut merepresentasikan referensi arus dan arus aktual secara proporsional.

Referensi arus yang diberikan adalah sebesar 2 A. Arus keluaran inverter tidak diumpan-balikkan pada sistem. Hasil pengujian arus keluaran inverter dengan SPWM open loop pada beban $4,6 \Omega$ dan $9,4 \Omega$.

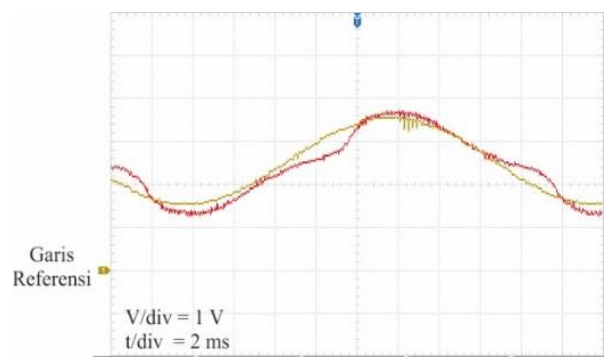

Gambar 15. Arus Keluaran Inverter Open Loop dengan Beban 4,6 $\Omega$ pada Referensi 2 A.

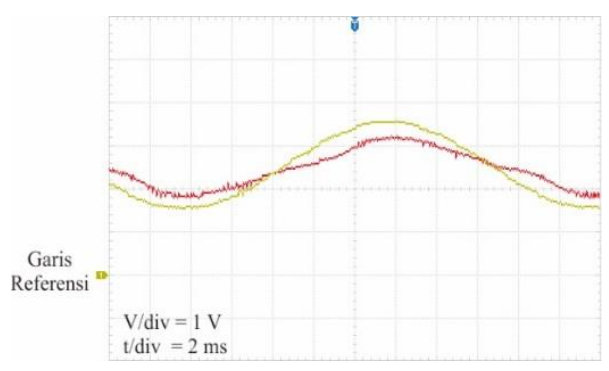

Gambar 16. Arus Keluaran Inverter Open Loop dengan Beban 9,4 $\Omega$ pada Referensi 2 A.

Gambar 15 dan Gambar 16 menunjukkan hubungan arus keluaran inverter (merah) dan referensi arus yang dibangkikan (kuning). Hasil pengujian arus keluaran inverter open loop pada referensi arus 2 A menunjukkan bahwa nilai arus keluaran akan berubah saat inverter mengalami perubahan beban. Nilai arus rms yang terukur pada tang ampere adalah 1,72 A untuk beban 4,6 $\Omega$ dan 0,98 A untuk beban $9,4 \Omega$. Hal ini cukup mendekati teori dimana nilai arus berbanding terbalik dengan nilai resistansi pada beban. Namun, dapat dilihat pada Gambar 15 dan Gambar 16 bahwa gelombang arus keluaran inverter dengan SPWM open loop tidak dapat mengikuti gelombang referensi arus yang diberikan.

\subsection{Pengujian Keluaran Inverter Satu Fasa dengan Kontrol Arus Histeresis}

\subsubsection{Pengujian Tegangan Keluaran Inverter}

Pengujian bertujuan untuk mengamati bentuk gelombang dan magnitude tegangan keluaran inverter satu fasa yang dipicu oleh sinyal kontrol histeresis. Referensi arus yang diberikan adalah sebesar 2 A. Arus keluaran inverter diumpan-balikkan pada mikrokontroler DSPIC30F4011. Hasil pengujian tegangan keluaran inverter dengan kontroler arus histeresis pada beban $4,6 \Omega$ dan $9,4 \Omega$. 


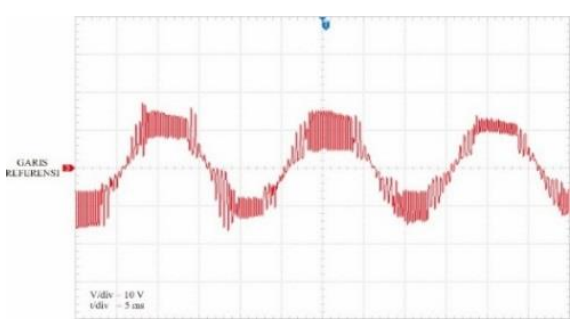

Gambar 17. Tegangan Keluaran Inverter Histeresis dengan Beban 4,6 $\Omega$ pada Referensi 2 A

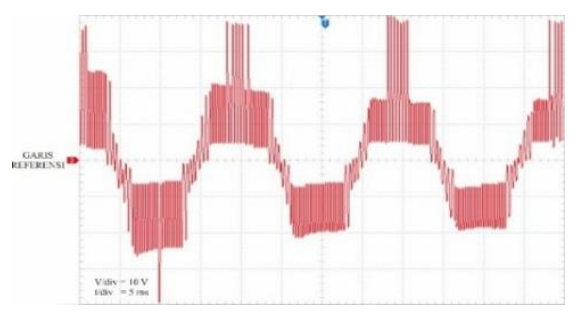

Gambar 18. Tegangan Keluaran Inverter Histeresis dengan Beban 9,4 $\Omega$ pada Referensi 2 A

Hasil pengujian tegangan keluaran inverter dengan kontroler histeresis pada referensi arus 2 A menunjukkan bahwa nilai tegangan keluaran akan berubah saat inverter mengalami perubahan beban. Nilai tegangan rms yang terukur pada multimeter adalah $10,99 \mathrm{~V}$ untuk beban $4,6 \Omega$ dan $16,9 \mathrm{~V}$ untuk beban $9,4 \Omega$. Hal ini sesuai dengan teori kontrol arus, dimana nilai tegangan keluaran inverter akan berubah ketika nilai resistansi beban berubah. Sehingga nilai arus yang mengalir pada beban akan tetap mengikuti referensi meskipun beban diubah-ubah.

Namun dapat dilihat pada gambar hasil pengujian tegangan bahwa pada gelombang tegangan banyak terdapat ripple. Adanya ripple disebabkan oleh efek pensaklaran yang dikontrol secara manual oleh kontroler histeresis. Nyala dan matinya saklar dipengaruhi oleh perbandingan error arus dan batas histeresis yang diberikan yaitu 0,01 ampere, sehingga terjadi ripple tegangan yang cukup besar.

\subsubsection{Pengujian Arus Keluaran Inveter}

Pengujian bertujuan untuk mengamati bentuk gelombang dan magnitude arus keluaran inverter satu fasa yang dipicu oleh sinyal kontrol histeresis. Arus keluaran diamati melalui tegangan keluaran DAC. Tegangan DAC tersebut merepresentasikan referensi arus dan arus aktual secara proporsional.

Referensi arus yang diberikan adalah sebesar 2 A. Arus keluaran inverter diumpan-balikkan pada mikrokontroler DSPIC30F4011. Hasil pengujian arus keluaran inverter kontroler arus histeresis pada beban $4,6 \Omega$ dan $9,4 \Omega$.

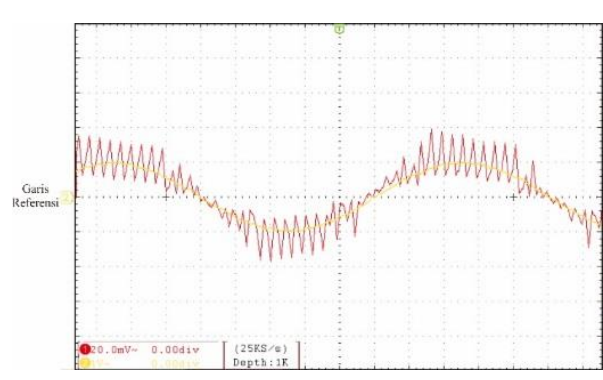

Gambar 19. Arus Keluaran Inverter Histeresis dengan Beban 4,6 $\Omega$ pada Referensi 2 A

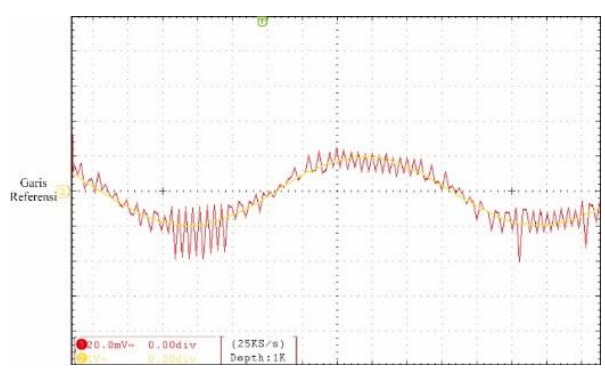

Gambar 20. Arus Keluaran Inverter Histeresis dengan Beban 9,4 $\Omega$ pada Referensi 2 A

Gambar 19 dan Gambar 20 menunjukkan hubungan arus keluaran inverter (merah) dan referensi arus yang dibangkikan (kuning). Hasil pengujian arus keluaran inverter open loop pada referensi arus 2 A menunjukkan bahwa arus keluaran sudah dapat mengikuti referensi yang diberikan. Arus keluaran inverter tetap dapat mengikuti referensi saat inverter mengalami perubahan beban.

Namun dapat dilihat pada gambar hasil pengujian terlihat bahwa pada gelombang arus keluaran banyak terdapat ripple. Adanya ripple disebabkan oleh efek pensaklaran yang dikontrol secara manual oleh kontroler histeresis. Nyala dan matinya saklar dipengaruhi oleh perbandingan error arus dan batas histeresis yang diberikan yaitu 0,01 ampere, sehingga terjadi ripple tegangan yang cukup besar. Ripple arus pada beban 4,6 $\Omega$ terlihat lebih besar dari pada beban $9,4 \Omega$, hal ini dikarenakan semakin kecil nilai beban maka nilai arus akan semakin besar, sehingga ripple yang dihasilkan pun semakin besar.

Referensi arus yang dibangkitkan setara dengan 2 ampere peak $\left(I_{m}\right)$, sehingga dengan Persamaan 4.1 didapatkan nilai referensi arus dalam rms sebesar 1,41 A.

Nilai arus rms yang terukur pada tang ampere adalah 2,03 A untuk beban 4,6 $\Omega$ dan 1,41 A untuk beban $9,4 \Omega$. Nilai arus rms terukur pada beban $9,4 \Omega$ sama dengan referensi arus yang dibangkitkan. Namun, pada beban $4,6 \Omega$ arus rms yang terukur memiliki selisih yang cukup signifikan dengan referensi. Hal ini dikarenakan ripple arus yang terbentuk pada arus keluaran pada beban 4,6 $\Omega$ turut terbaca oleh alat ukur arus, sehingga nilai yang ditampilkan memiliki selisih yang signifikan terhadap nilai sebenarnya. 
Hasil pengujian inverter satu fasa dengan kontroler arus histeresis pada variasi referensi arus dengan rentang $1-3$ A dapat dilihat pada Tabel 2 berikut.

Tabel 2. Hasil Pengujian Inverter Satu Fasa dengan Kontrol Arus Histeresis

\begin{tabular}{|c|c|c|c|c|c|c|}
\hline \multicolumn{4}{|c|}{ Beban 4,6 $\Omega$} & \multicolumn{3}{|c|}{ Beban $9,4 \Omega$} \\
\hline $\begin{array}{l}\text { Refere } \\
\text { nsi (A) }\end{array}$ & $\begin{array}{c}\text { Teganga } \\
n(V)\end{array}$ & $\begin{array}{c}\text { Arus } \\
\text { (A) }\end{array}$ & $\begin{array}{l}\text { Erro } \\
r(A)\end{array}$ & $\begin{array}{c}\text { Teganga } \\
\mathrm{n}(\mathrm{V})\end{array}$ & $\begin{array}{l}\text { Arus } \\
\text { (A) }\end{array}$ & $\begin{array}{c}\text { Error } \\
\text { (A) }\end{array}$ \\
\hline 1 & 4,65 & 1,14 & 0,70 & 11,1 & 0,88 & $-0,17$ \\
\hline 1,5 & 9,6 & 1,6 & 1,06 & 13,8 & 1,2 & $-0,13$ \\
\hline 2 & 10,99 & 2,03 & 1,41 & 16,9 & 1,41 & 0,004 \\
\hline 2,5 & 11,77 & 2,48 & 1,76 & 19,6 & 1,78 & $-0,01$ \\
\hline 3 & 12,1 & 2,62 & 2,12 & 20,5 & 2,14 & $-0,01$ \\
\hline
\end{tabular}

\section{Kesimpulan}

Kontrol arus dengan Metode Histeresis telah berhasil diimplementasikan pada inverter satu fasa tipe Full Bridge, sehingga arus keluaran inverter dapat diatur mengikuti referensi yang diinginkan. Mikrokontroler DSPIC30F4011 dapat digunakan dengan baik untuk menghasilkan sinyal kontrol Histeresis sebagai sinyal pemicuan pensaklaran MOSFET pada inverter satu fasa. Gelombang arus keluaran pada inverter dengan SPWM open loop tidak dapat mengikuti referensi arus yang diberikan. Dengan rata-rata error arus sebesar 0,62 A untuk beban $4,6 \Omega$ dan 0,38 A untuk beban 9,4 $\Omega$. Gelombang arus keluaran pada inverter dengan kontroler arus Histeresis dapat mengikuti referensi arus dengan baik, meskipun nilai resistansi beban diubah. Rata-rata error arus pada inverter dengan kontroler arus Histeresis sebesar $0,55 \mathrm{~A}$ untuk beban 4,6 $\Omega$ dan 0,06 A untuk beban $9,4 \Omega$. Nilai error yang cukup besar pada beban 4,6 $\Omega$ disebabkan oleh ripple arus yang terukur oleh tang ampere sehingga nilai arus yang ditampilkan memiliki selisih yang cukup besar dengan nilai referensinya. Adanya ripple pada tegangan dan arus keluaran inverter dengan kontroler arus Histeresis disebabkan oleh pensaklaran MOSFET yang keadaan on dan off-nya dipicu oleh sinyal kontrol histeresis, dimana sinyal kontrol tidak membentuk pola yang teratur. Hal ini dikarenakan sinyal kontrol akan berpindah state dari 0 ke 1 dan dari 1 ke 0 secara instan berdasarkan perbandingan nilai error dan batas histeresis yang diberikan.

\section{Referensi}

[1]. N. A. R. Krismadinata and J. Selvaraj, "Hysteresis Current Control and Sensorless MPPT for GridConnected Photovoltaic Systems," 2007 IEEE Int. Symp. Ind. Electron., no. L, pp. 572-577, 2007.

[2]. P. A. Dahono and I. Krisbiantoro, "New hysteresis current controller for single-phase full-bridge inverters," IET Power Electron., vol. 2, no. 5, pp. 585-594, 2009.

[3]. M. Salman, M. Ashari, and H. Suryoatmojo, "Perancangan Inverter Satu Fasa Yang Terhubung Dengan Jaring Distribusi Menggunakan Metode Hysterisis Current Control," Proceeding Semin. Tugas Akhir, pp. 1-7.

[4]. X. Dai and Q. Chao, "The research of photovoltaic gridconnected inverter based on adaptive current hysteresis band control scheme," 1st Int. Conf. Sustain. Power Gener. Supply, SUPERGEN '09, 2009.

[5]. G. Raţă and R. Marschalko, "Development of hysteresis modulation methods for PWM AC - to - DC converters based on dead - Beat control," 2006 IEEE Int. Conf. Autom. Qual. Testing, Robot. AQTR, pp. 220-224, 2006.

[6]. TOSHIBA, "TOSHIBA Photocoupler GaAlAs Ired \& Photo-IC TLP 250," vol. 5, pp. 1-8, 2007.

[7]. Intersil, "Mur1540, mur1560, rurp1540, rurp1560," no. 2778, pp. 1-4, 2000.

[8]. S. Muttaqin, I. Setiawan, and M. Facta, "DESAIN DAN IMPLEMENTASI VOLTAGE-SOURCE INVERTER ( VSI ) TIGA FASE SINUSOIDAL PULSE-WIDTH MODULATION ( SPWM ) DENGAN DSPIC30F4011," TRANSMISI, vol. 18, no. 4, 2016.

[9]. Allegro, "ACS712 Fully Integrated, Hall Effect-Based Linear Current Sensor IC," pp. 217-219, 2017.

[10]. R. De Doncker, D. W. J. Pulle, and A. Veltman, Advanced Electrical Drives: Analysis, Modeling, Control. Springer Science+Bussiness Media, 2011.

[11]. B. V. Ranganadh, A. M. Prasad, and M. Sreedhar, "Modelling And Simulation Of A Hysteresis Band Pulse Width Modulated Current Controller Applied To A Three Phase Voltage Source Inverter By Using Mat lab," IJAREEIE, vol. 2, no. 9, pp. 4378-4387, 2013. 